\title{
Intervening Agency and Civilian Liability
}

\author{
Helen Frowe ${ }^{1} \mathbb{D}$
}

Accepted: 6 December 2020 / Published online: 27 January 2021

(c) The Author(s) 2021

\begin{abstract}
Adam Hosein has recently proposed that a sufficient degree of intervening agency between a person's contribution to an unjust lethal threat and the posing of that threat can exempt the contributor from liability to defensive killing. Hosein suggests that this will exempt most civilians from liability to lethal defence even if they contribute to unjust killings. I argue that intervening agency does not bear on a person's responsibility for a threat, and does not exempt her from liability to defensive killing.
\end{abstract}

Keywords Liability to defensive harm · Civilian immunity · Intervening agency · Moral responsibility

\section{Introduction}

'Intervening agency' is used in two ways in the philosophical literature, both of which are illustrated by Bomb:

This paper was written for a conference forming part of the ERC-funded project on The Individualisation of War, hosted by the European University Institute in 2018. I am grateful to participants for their comments. Thanks also to Kasper Lippert-Rasmussen and Victor Tadros for helpful discussion. This research was supported by the Knut and Alice Wallenberg Foundation, Grant No. 1521101.

Helen Frowe

helen.frowe@philosophy.su.se

1 Stockholm University, Stockholm, Sweden 
Bomb: A designs a bomb. B builds the bomb. C, a British combatant, drops the bomb on German factory as part of Britain's war effort. In retaliation, G, a German combatant, drops a bomb on a British factory.

Some writers describe G's action as an instance of intervening agency between C's action and the destruction of the British factory. ${ }^{1}$ However, I take this kind of triggering of, but not providing a means for, someone else's action to be a morally distinct phenomenon that I will not address here. ${ }^{2}$

Rather, I am interested in intervening agency of the sort that happens between A, B and C, culminating in C's bombing of the German factory-that is, cases in which indirectly contributing agents (here, A and B) provide a means of bringing about an outcome, of which $\mathrm{C}$ is the proximate or direct cause. (From hereon in, I use 'indirect contributors' to identify those who actions contribute to threats only if other agents later intervene in the causal chain. I use the term 'direct threateners' to describe those who, like $\mathrm{C}$, directly pose threats.)

Writing in this journal, Adam Hosein claims that I defend Parity:

Parity: Non-combatants and combatants on an unjust side of a war are frequently on a par with respect to their responsibility for threats posed by their country, and thus frequently on a par with respect to their liability to being harmed. $^{3}$

Parity undermines the widely-held view that civilians are not liable to defensive killing in war.

Hosein argues that we can reject Parity if intervening agency bears on one's moral responsibility for an unjust threat. ${ }^{4}$ Hosein proposes Weak Intervening Agency:

Weak Intervening Agency: People bear less responsibility for a harm the less proximate they are to a harm, and this weakened responsibility bears on their liability. ${ }^{5}$

Hosein does not specify how diminished responsibility bears on liability. However, several remarks suggest that he takes their diminished responsibility to exempt indirect contributors from liability to defensive killing, rather than to defensive harm altogether. $^{6}$

\footnotetext{
1 See e.g. Jeff McMahan, "What Rights May Be Defended By Means of War?", C. Fabre and S. Lazar (eds), The Morality of Defensive War (Oxford: Oxford University Press, 2014): pp. 115-158, p. 130.

2 But see Helen Frowe, Defensive Killing (Oxford: Oxford University Press, 2014): pp. 127-139; Helen Frowe, 'Defending Defensive Killing: Reply to Barry, McMahan, Ferzan, Renzo and Haque', Journal of Moral Philosophy, 15(6) (2018): pp. 750-766.

3 Adam Omar Hosein, "Spare No One? A Review Essay”, Criminal Law and Philosophy, 13(1) (2019): pp. 187-203, p. 188.

4 Hosein, "Spare No One?", p. 195.

5 Hosein, "Spare No One?", p. 191.

${ }^{6}$ Hosein suggests that indirect contributors "aren't liable to be harmed in the ways that [a direct contributor] is liable to be harmed" (p. 193), and talks of civilians as "less liable to be killed" (p. 195). He also talks of "significant differences" in the liability of civilians and combatants, but doesn't say that civilians are not liable to any defensive harm (p. 195).
} 
In this paper, I argue that intervening agency does not bear on a contributor's responsibility for a threat, and thus does not preclude indirect contributors' being liable to defensive killing. If my arguments are sound, they also rebut the stronger view that intervening agency precludes civilians' being liable to defensive harm altogether.

In Section Two, I outline Hosein's proposal that intervening agency diminishes moral responsibility for an unjust threat, and that repeated interventions increasingly diminish responsibility, causing some indirect contributors to fall below the threshold for liability to lethal defence. In Section Three, I argue that this view wrongly distinguishes between morally identical contributors. Section Four addresses the view that an indirect contributor can be liable to defensive killing, but only if she either effectively controls a directly threatening agent, or jointly perpetrates wrongs. I argue that this is either false-that is, it is not only in cases of joint perpetration that indirect contributors can be so liable-or we must broaden our account of joint perpetration in a way that will likely include many civilians. Section Five suggests that the intuitions elicited by cases involving intervening agency are most plausibly explained by presumed differences in the foreseeability of harm, and necessity of harming indirect contributors. Section Six concludes.

\section{Intervening Agency}

In earlier work, ${ }^{7}$ I argued that cases such as Gun and Coercion falsify the claim that intervening agency defeats liability to defensive killing:

Gun: Attacker tells Friend that Attacker is going to kill Victim, but has lost his gun. Attacker nags Friend to lend him a gun. Friend eventually tires of Attacker's nagging, and lends Attacker the gun. Attacker tries to kill Victim.

Coercion: The German army captures a town. Nazi orders Mayor to shoot Citizen, on pain of Nazi's shooting a greater number of citizens (but not enough to justify killing Citizen, who would otherwise have lived). ${ }^{8}$

Imagine that in Gun, Victim can defend himself only by killing Friend, and in Coercion Citizen can defend himself only by killing Nazi. I argued that Friend and Nazi are liable to defensive killing despite the intervening agency of the direct threateners. Hence, intervening agency does not defeat liability to lethal defence.

Hosein argues that Weak Intervening Agency can reconcile the intuitive liability of Friend and Nazi with the moral significance of intervening agency. According to this principle, intervening agency diminishes the responsibility of those further back in the causal chain. Hosein argues that the degree of diminishing is affected by both the number of interventions between a contribution and a harm, and the strength of an intervener's agency. Hosein agrees that Friend is liable to be killed

\footnotetext{
7 Frowe, Defensive Killing, pp. 168-171.

8 Coercion comes from Cheyney Ryan, "Self-Defence, Pacifism and the Possibility of Killing", Ethics, 93(3) (1983): pp. 508-524, p. 515.
} 
in Gun, because "the mere fact that I am slightly less proximate to the threat isn't sufficient to undermine my liability". ${ }^{9}$ But, he argues, someone further back in the causal chain, whose contribution is followed by numerous interventions, might not be so liable. Hosein also agrees that Nazi is liable to be killed in Coercion. But, he argues, this is partly because Mayor's agency is "heavily compromised", as a result of Nazi's coercion. ${ }^{10}$ This means that there is very little intervening agency between Nazi and the threat to Citizen. Hence, "it is unsurprising that the Nazi's responsibility is undiminished (or very minimally diminished) and the case does not demonstrate that intervening agency cannot reduce responsibility." 11

Hosein suggests that, in general, combatants' intervening agency is more potent than Mayor's: even though combatants act under orders, they are typically more than minimally responsible. Thus, their interventions have a stronger diminishing effect on civilians' responsibility than Mayor's intervention has on Nazi's responsibility. And, in general, there will be multiple intervening agents between civilians and the inflicting of harms in war-not only rank-and-file combatants, but also politicians and military leaders, whose agency is yet more potent than combatants'. ${ }^{12}$ Given these factors, civilians' responsibility will typically be much less than that of combatants.

Of course, both Hosein and I grant that mere differences in responsibility do not entail differences in liability. Hosein's argument holds that intervening agency diminishes responsibility, but indirect contributors cease to be liable to defensive killing only at a certain point in the agential chain. Until this point, then, indirect contributors are less responsible than more proximate contributors and direct threateners, but still liable to be killed.

Given this, Hosein's framing of Parity in terms of equal responsibility underpinning equal liability is a bit unhelpful. My argument for civilian liability does not depend on the claim that civilians and combatants are on a par with respect to their responsibility for the unjust threats of war. It requires only that civilians are sufficiently responsible for those threats to ground liability to defensive killing. And thus what Hosein must show, then, is not that intervening agency produces differences between civilian responsibility and combatant responsibility, but rather that intervening agency typically diminishes civilians' responsibility to the extent that it falls below the threshold for liability to defensive killing.

Notice that for Weak Intervening Agency to support civilian immunity to defensive killing, it cannot be a purely retrospective claim-that is, it cannot hold that one's responsibility diminishes only once others have intervened and one's contributing lies in the past. If that were true, civilians would, at the time they make weapons and other goods, be fully responsible for the harms that their contributions will later bring about. At this point, there will have been no interventions further down the chain to diminish their responsibility, because they will be the current end of the

\footnotetext{
${ }^{9}$ Hosein, 'Spare No One?', p. 190.

10 Hosein, 'Spare No One?', p. 192.

11 Hosein, 'Spare No One?', p. 192.

12 Hosein, 'Spare No One?', p. 193.
} 
causal chain. Rather, the principle must also hold that the fact that getting from the making of the weapons to the inflicting of harm requires prospective interventions diminishes someone's responsibility at the time she makes her contribution. On this view, an IED-maker's liability at the time she makes the devices is undermined if getting the IEDs into the ground where they will later kill people requires multiple future interventions by other responsible agents.

\section{Intervening as Diminishing Responsibility}

\section{Consider Fuel:}

Fuel: A group of ten people-A-J-discover a tiny fire in a house that is about to burn out. They decide to make it a big fire. They stand in a line, passing logs down the chain. A, the last in the chain, throws the logs on the fire. Each of A-J knows that Owner is trapped in the house Owner will be killed if the fire reaches a certain size. Killing any one member of the chain will prevent the fire from passing that threshold. Owner can save her life only by killing one of A-J.

According to Hosein, A is distinctively responsible for the fire, and the responsibility of each contributor progressively decreases as we move from A up the causal chain to $\mathrm{J} .{ }^{13}$ But it strikes me as implausible that Owner has special reason to kill A rather than another, indirect contributor, or that she may not kill any of the indirect contributors, or that she may kill B or $\mathrm{C}$, but not $\mathrm{H}$ or $\mathrm{I}$.

Thinking about Fuel suggests that the (allegedly) minimal nature of Mayor's agency in Coercion does not even partly explain why Nazi's liability persists in the face of Mayor's intervention. Mayor's minimal agency might help to explain the moral worseness of killing Mayor rather than killing Nazi, although this could also be explained by other morally significant differences between them-for example, that Nazi is more deserving of harm, or that Nazi wrongs Mayor by coercing him. ${ }^{14}$ But A's agency is not minimal in Fuel, and yet each of A-J is not only liable to defensive killing by Owner but also, I suggest, equally responsible for the fire, irrespective of their position in the chain. When we hold other things equal, intervening agency is morally irrelevant. But, according to Weak Intervening Agency, responsibility diminishes as we move up the chain. $G$ is less responsible for the fire than F. And, for this to support the claim that some indirect contributors are not liable to defensive killing, there must be a point in the chain at which responsibility is so diminished that the earliest contributors cease to be liable.

\footnotetext{
13 I discuss below whether joint perpetration might render intervening agency irrelevant. Set that aside for now: my point here is that intervening agency isn't significant at least when people act together in the way described in Fuel.

14 See Massimo Renzo, 'Manipulation and Liability to Defensive Harm' (ms.) for defence of similar claim with respect to manipulators.
} 
Hosein doesn't speculate as to how much intervening agency suffices to defeat liability to lethal harm - that is, at what point in the chain the contributors cease to be liable. Of course, we might think it unreasonable to ask for anything specificlots of moral thresholds are vague. But this doesn't make it any more plausible that, for example, $\mathrm{G}$ is less responsible for the fire than $\mathrm{F}$. We might also suggest that this chain isn't long enough for anyone to avoid liability. But the number of interventions necessary for defeating liability cannot be much higher than nine if Weak Intervening Agency is meant to support widespread civilian immunity-indeed, nine may already be too high to rule out many civilian contributors. One of the difficulties of relying on intervening agency to support civilian immunity is that the number of agential interventions between civilian contributions and killings will vary significantly, and there's no reason to think that this number will always be very high.

I think that Weak Intervening Agency is decisively undermined by comparing Fuel with Circle:

Circle: The same group of ten people as in Fuel-A-J-discover a tiny fire in a house that is about to burn out. They decide to make it a big fire. They stand in a circle, each throwing logs on the fire. Each of A-J knows that Owner is trapped in the house Owner will be killed if the fire reaches a certain size. Killing any one member of the chain will prevent the fire from passing that threshold. Owner can save her life only by killing one of A-J.

In Circle, each member of the group poses a proximate threat to Owner, and Hosein's view will pronounce each of A-J liable to defensive killing. But whether B-J are liable to defensive killing, and thus whether Owner may kill them, cannot depend on whether they arrange themselves in a line or a circle in order to burn down the house. If so, Weak Intervening Agency is false.

\section{The Exception for Joint Perpetrators}

Adil Ahmad Haque argues that those who indirectly contribute to unjust killing, rather than directly killing, do not violate duties of sufficient stringency to render them liable to defensive killing. ${ }^{15}$ Haque claims that when someone unjustifiably breaches a duty, her liability is limited to the cost that she was initially required to bear rather than breach that duty. And, he argues, whilst we ought to bear lethal costs rather than kill innocent people, we need not bear lethal costs rather than indirectly contribute to the killing of innocent people. Since an indirect contributor is not required to bear a lethal cost rather than contribute to an unjust killing, she cannot become liable to lethal defence if she unjustifiably contributes to that threat. ${ }^{16}$ The fact that one is an indirect contributor thus precludes one's being liable to defensive killing.

15 Haque, Law and Morality at War, pp. 70-71.

16 Haque, Law and Morality at War, pp. 70-71. 
However, Haque grants two exceptions to this rule, arguing that a person can be liable to defensive killing if she either indirectly threatens through the actions of someone she effectively controls, or jointly perpetrates harm by acting with others. ${ }^{17}$

For example, Haque will pronounce Nazi in Coercion liable to be killed because Nazi threatens through Mayor, controlling Mayor 'like a tool'. ${ }^{18}$ Haque suggests that military commanders are also liable on these grounds, since the combatants who do their bidding are committed to following their orders, and thus can be manipulated by them. However, combatants together undertaking a combat operation are joint perpetrators of the harms they inflict. For example, someone who drives the van for an ambush is liable to defensive killing for the sake of those whom she helps threaten, even though she will not directly kill anyone, because of her "integral role" in a "co-ordinated military operation". ${ }^{19}$

One response to the Fuel case that we discussed in 3, then, could be to say that all the contributors-direct or indirect-are joint perpetrators of the fire (and of the threat to Owner), and that the moral significance of intervening agency is defeated in cases of joint perpetration. This explains why each contributor is liable to lethal defence without undermining the significance of intervening agency in the absence of joint perpetration. This is, roughly, how David Rodin tries to secure the liability of all combatants, claiming that their "unity of intent" and role in an "institutionalised chain of command" makes them liable to defensive killing even if they are not proximate threats. ${ }^{20}$ In the case of civilians who aren't joint perpetrators, however, intervening agency will diminish their liability. Perhaps Weak Intervening Agency can be modified to exclude cases of joint perpetration, enabling it to accommodate Fuel.

I doubt that only those indirect contributors who are joint perpetrators can be liable to defensive killing. Consider Informant:

Informant: Albert realises that his neighbours are concealing Beth, a Jew, in their attic. Nobody else suspects this. Albert plans to tell the Nazi authorities, who will raid the house in order to send Beth to a concentration camp, where she will be killed. Beth can prevent Albert's informing on her only by killing him. $^{21}$

Albert is not directly threatening harm to Beth or controlling the Nazi officers. Nor does he jointly perpetrate harm: he will not be part of the raid, and to inform is not to be part of a coordinated military operation. And yet I find it deeply implausible that Beth may not kill Albert to save her own life. It seems equally implausible that

\footnotetext{
17 Haque, Law and Morality at War, p. 62.

18 Haque, Law and Morality at War, p. 64.

19 Haque, Law and Morality at War, p. 59.

20 David Rodin, 'Morality and Law in War', in H. Strachan and S. Scheipers (eds.), The Changing Character of War (Oxford: Oxford University Press, 2011), pp. 446-63, p. 449. I've argued elsewhere that an account of joint perpetration that includes most combatants is unlikely to exclude most contributing civilians. See Defensive Killing, pp. 170-172.

21 My discussion in this section builds upon that in Frowe, 'Civilian Liability', Ethics, 129(4) (2019): pp. 625-650.
} 
Beth may not kill Albert after he has informed on her if doing so will enable her to escape the Nazis.

If Albert is liable to be killed, it cannot be true that only those indirect contributors who act through others by controlling them, or who jointly perpetrate harm, can be liable to defensive killing. Informant also gives us further reason to doubt that Hosein's claim that repeated intervening agency defeats liability. There will be multiple interventions between Albert's informing and harm befalling Beth. For example, Albert will speak to the desk officer at the local Nazi party headquarters, who will pass Albert's information on to someone else, who will pass it to a superior officer who will then decide whether to act on it, who will then order others to carry out the raid, who will then capture Beth, who will then hand her over to people who will put her on a train, which will take her to a concentration camp. All these interventions take place before Beth even gets to the camp at which she will eventually be killed. Nothing about these interventions makes me think that Albert is not liable to be killed to save Beth.

If Albert is indeed liable to defensive killing in Informant, we must either deny that indirect contributors can be liable only if they control or jointly act with direct perpetrators, or broaden our account of joint perpetration to include someone like Albert. ${ }^{22}$ Perhaps knowingly playing this role in the threat to Beth suffices to make Albert a joint perpetrator. But any account broad enough to include Albert as a joint perpetrator is also going to include many civilians. If providing information that results in unjust killing is enough to make one a joint perpetrator, providing weapons and other material goods to carry out unjust killings should also suffice. ${ }^{23}$

\section{Debunking Intervening Agency}

I suggest that cases that seem to support the moral significance of intervening agency are in fact best explained by either variations in the foreseeability of a threat's eventuating, or in the necessity of using force to avert that threat. As I argue here, being properly sensitive to foreseeability and necessity debunks the alleged significance of intervening agency.

\subsection{Foreseeability}

Consider Hosein's example of a gun that passes down a long chain of people until it reaches the killer. ${ }^{24}$ I suggest that the intuition that those further up the chain are not liable to defensive killing is partly explained by the assumption that those contributors simply don't know, or are less able to predict, what they are contributing to. The person working on the gun counter at Walmart who sells a gun that is eventually

\footnotetext{
${ }^{22}$ It seems very unlikely that any plausible account of controlling will rule that Albert controls the people who kill Beth.

23 Haque, Law and Morality at War, pp. 60-61, p. 65.

${ }^{24}$ Hosein, 'Spare No One?', p. 193.
} 
used in an armed robbery is in a different epistemic position than the person who lends it specifically to the robber to be used in the robbery. On the assumption that one's epistemic position affects one's moral responsibility, the decreasing foreseeability that one is contributing to a threat plausibly bears on one's liability. Of course, we don't require certainty that one poses or contributes to a threat for liability. But, plausibly, it matters whether a harm is a foreseeable upshot of one's action (which might vary depending on one's account of foreseeability). ${ }^{25}$

Indeed, we might think that the length of a causal chain necessarily bears on foreseeability, if we assume that the higher the number of necessary interventions between a contribution and an outcome, the less likely that outcome is to occur. ${ }^{26}$ For example, Sanford Kadish argues that, "the intervention of a second actor, whose action is required for the harm to occur, reduces the probabilities that the harm would ultimately happen." ${ }^{, 27}$ If so, contributors at different points in the chain cannot predict with equal confidence that their contributions will help to bring about the outcome. Thus, it seems that an increasing number of interventions must produce a corresponding decrease in foreseeability.

Note that this would not make intervening agency significant for responsibility per se-it would still be foreseeability doing the moral work. But if intervening agency necessarily decreases foreseeability, intervening agency could nonetheless be a proxy for decreased responsibility.

However, I doubt that intervening agency does necessarily decrease foreseeability. On the contrary, increasing the number of people who contribute to an outcome can decrease the burden on each participant, making her more likely to do her share, and thus increase the foreseeability of the threat's eventuating in harm. Consider, for example, how multiple intervening agents carrying a baton in a relay race can increase the likelihood of the baton's getting from the start line to the finish line. One runner alone might not make the distance; four runners, one intervening after the other to carry the baton, increases the chances of the outcome's occurring - that is, of the baton's crossing the finishing line. Thus, further instances of intervening agency cannot necessarily diminish foreseeability within a causal chain. ${ }^{28}$

It also seems unlikely that longer causal chains, requiring more interventions, are in general less likely to eventuate in harm or threats of harm than shorter causal chains that require fewer interventions. Foreseeability depends on a wide range of factors, such as the degree of each contributor's commitment to the end, and will not consistently decrease with increased interventions. That more people are committed

\footnotetext{
25 See, for example, McMahan's discussion of Cell Phone, in which an agent has no idea, and no reason to suspect, that his phone has been wired by a villain to set off a bomb. Jeff McMahan, "The Basis of Moral Liability to Defensive Killing”, Philosophical Issues, 15 (2005): pp. 387-405, p. 397.

26 This was suggested to me by Kasper Lippert-Rasmussen.

27 Sanford Kadish, "Reckless Complicity", The Journal of Criminal Law and Criminology, 87(2) (1997): pp. 369-394, p. 318.

28 See also Saba Bazargan-Forward, "Accountability and Intervening Agency: An Asymmetry Between Upstream and Downstream Actors", Utilitas, 29(1) (2017): pp. 110-124, p. 114.
} 
to bringing about an end may increase each agent's resolve to do her bit, thus making the outcome more likely than if she acted alone, or as part of a shorter causal chain. Of course, we might have a threshold for when a harm counts as foreseeable for the purposes of grounding liability. This is something that liability theorists have discussed at some length. ${ }^{29}$ But this discussion need not detain us here, for two reasons. First, it is not unforeseeable that the guns, bullets and other items that civilians make in munitions factories will be used to kill people. On the contrary, killing, or threatening to kill, is the point of these items, and the chances that they will be so used are plausibly high enough (at least in nearly all actual wars) for this foreseeability to ground liability.

Moreover, many civilians do not merely foresee that their contributions will aid their combatants' military efforts, but also intend that they do so. And I doubt that differences in foreseeability matter when one intends to bring about an outcome. Consider Bullets:

Bullets: Enemy wants to kill Victim. All six chambers of Enemy's gun are loaded. The gun is heavy, so Enemy takes out a bullet. He points the gun at Victim and pulls the trigger, killing Victim.

Enemy knows that he is less likely to cause Victim's death once he removes a bullet. It is thus less foreseeable that Victim will die. But it is implausible that Enemy is now less responsible for Victim's death than he would have been had he not removed the bullet. It might even be enough for liability that one hopes that one will bring about an outcome, even if one believes that the chances of success are tiny and thus one cannot be properly said to intend the outcome (assuming that an agent's intending to bring about an outcome requires her to think that there is a nonnegligible chance of the outcome's occurring). Thus, there are reasons to doubt that intervening agency necessarily or even generally affects foreseeability, and to doubt that such an effect could support widespread civilian immunity.

\subsection{Necessity}

Our intuitions about the permissibility of harming civilians might also reflect familiar worries about preventive force-that is, force used before a threatened harm is imminent. Roughly, the more nascent a threat, the less confident we can be that force is necessary to avert it. This doesn't matter when we're thinking about harming indirect contributors to a threat that is now imminent, of course. But it could make us cautious about the use of force against, say, the IED-maker. Perhaps the members of the militia will be captured before they have a chance to lay the IEDs. This suggests that the fact that the IED-maker's plan requires the intervention of other agents affects the permissibility of harming her.

\footnotetext{
${ }^{29}$ E.g. the many discussions of McMahan's Conscientious Driver and Cell Phone cases. See, for example, Jeff McMahan, "The Basis of Moral Liability to Defensive Killing", p. 397; Kimberly Ferzan, "Culpable Aggression: The Basis for Moral Liability to Defensive Killing", Ohio State Journal of Criminal Law, 9(2) (2012): pp. 669-697; Jonathan Quong, "Rights Against Harm", Proceedings of the Aristotelian Society, 89 (2015): pp. 246-266.
} 
But, again, this doesn't show the significance of intervening agency as such: what does the moral work here is the probability of the threat's eventuating in harm. We can see this by noticing that the same concern arises in cases of a non-imminent threat posed by a single person. Say that the IED-maker will lay the devices herself, but first needs to drive to the right place, which will take her several days. If there's no increased risk connected to waiting until she arrives and starts laying the devices, then, here too, we ought to wait in case she changes her mind, or is otherwise thwarted. But there's no intervening agency that could explain this requirement not to kill her at the point when she makes the devices. Intervening agency can affect the probability of a threat's eventuating, but this does not mean intervening agency necessarily diminishes moral responsibility. Rather, this is just an instance of the general truth that the lower the chance of a threat's eventuating, the less likely force is to be necessary. This bears on the permissibility of harming a person to avert a threat. But it does not bear on her responsibility for posing that threat. And, as we saw above, intervening agency can also increase the chance of a threat's eventuating in harm by decreasing each person's contribution, making contributing less burdensome. And, again, thinking about the probability of a threat's eventuating seems unlikely to provide general protection for civilians contributing to unjust wars, since the chances that civilians will in fact contribute to unjust threats will often be very high.

\section{Conclusion}

I have argued that intervening agency does not bear on a person's liability to defensive killing. Thus, we cannot rely on agential interventions between civilian contributions and unjust harming in war to support the view that civilians cannot be liable to defensive harm in war. Rather, as I have argued, it is plausible that our intuitions about the non-liability of indirect contributors track assumptions about foreseeability and necessity rather than intervening agency. These assumptions provide little support for the claim that civilians contributing to unjust wars enjoy widespread non-liability to defensive killing.

\section{Funding Open Access funding provided by Stockholm University.}

Open Access This article is licensed under a Creative Commons Attribution 4.0 International License, which permits use, sharing, adaptation, distribution and reproduction in any medium or format, as long as you give appropriate credit to the original author(s) and the source, provide a link to the Creative Commons licence, and indicate if changes were made. The images or other third party material in this article are included in the article's Creative Commons licence, unless indicated otherwise in a credit line to the material. If material is not included in the article's Creative Commons licence and your intended use is not permitted by statutory regulation or exceeds the permitted use, you will need to obtain permission directly from the copyright holder. To view a copy of this licence, visit http://creativecommons.org/licen ses/by/4.0/.

Publisher's Note Springer Nature remains neutral with regard to jurisdictional claims in published maps and institutional affiliations. 